\title{
The Dialectical Relationship between Religion and the Ideology of Science
}

\author{
Steven Gerardi \\ New York City College of Technology (CUNY), New York, USA \\ Email: SGerardi@Citytech.Cuny.edu
}

Received May 12 $2^{\text {th }}$, 2011; revised August 13 ${ }^{\text {th }}$, 2011; accepted September 20 ${ }^{\text {th }}, 2011$

\begin{abstract}
This original effort suggests that analogous to Max Weber's "Spirit of Capitalism" found in the Protestant Ethic and the Spirit of Capitalism, the disenchantment and demystification of the ancient Judaism ethic code of behavior, is a major factor in the rise of the ideology of science.
\end{abstract}

Keywords: Salvation Doctrines; Disenchantment; Principle of Rationality

\section{The Dialectical Relationship between Religion and the Ideology of Science and Technology Introduction to the Principle of Rationality}

Max Weber's (1864-1920) most important observations was the extensive influence religion has had on the modernization of Western Society. In Economy and Society Max Weber reveals his major concept of Rationality, and the historical-religious transformation process known as disenchantment. The Principle of Rationality is the degree to which a society displaces or replaces irrational thought with rational thought. A significant component found in the Principle of Rationality is "disenchantment". Disenchantment is the impersonal and objective human relationship located within Rationality. For Weber this force accounts for the rise and fall of institutional structures, classes and parties. Furthermore, Weber suggested that disenchantment is a major force in producing social change.

Rationality consists of two types of movements within social development-substantive and formal.

Substantive rationality or the traditional society is characterized by personal relationships and is without the purely measured acts of economic calculable. According to Weber, substantive forms are rooted in the recurrent and normal needs of the workday, usually with a patriarchal figure as routine leader of daily chores.

According to Weber, a charismatic/patriarchal leader arises because he holds a specific gift of the body and spirit, which was believed also to be supernatural or given to him by God. Within this society the image of the world is based on concrete magic, and religious dogma centered on mystical experiences. On the other hand, formal rationality is antagonistic to substantive or traditional rationality because formal rationality is a "modern state" with "advanced institutions" based on a "money economy" which has become synonymous with occidental development.

Formal rationality embraces a bureaucratic authority both in the private economy and the political sectors. Moreover, Weber suggested that bureaucratic authority's objective discharge of business in a "precise, unambiguous, and continuous manner", has become in part, Western Culture.

Within formal rationality a process occurs which changes humanity's thinking and attitudes concerning the image of the world. Weber labels this historic-religious transformation disenchantment. Weber saw this process as a general trend in Western Civilization as being an iron cage. In his view, there is no way out, no returning to a time in which the world would be viewed through magical or religious imagery. Additionally, this transformation was blocked everywhere, except for Western Civilization. Disenchantment can be seen as the degree to which the magical elements of thought are displaced by that of the rational, intellectual and an objective articulation of the image of the world. The masteries of nature and the "mystic experience" to a large extent, progress to an intellectual, impersonal, calculating image based in rules and scientific laws. Hence, this attitude seeks the "meaning of inner-worldly occurrences" through empirical and scientific thought. Thus, it is pushing back religion and the supernatural into the realm of the irrational, reducing human relations to an objective and impersonal stance.

Weber in his work the Protestant Work Ethic and the Spirit of Capitalism states that the protestant sect of Calvinism changed Western Civilization by suggesting that hard work and the accumulation of wealth was in fact God's work. The more wealth one accumulates, the more good work for God can be performed leading to eternal life at the right hand of God. John Calvin and his followers believed in pre-destination. In an effort to fulfill their perceived destiny, this group found it necessary to work hard, accumulate wealth, and invest this wealth to gain more wealth. This perceived destiny stated above, lead to the basis of American Capitalism. In Europe this Christian sect was persecuted, and settled in what is now the United States of America. The founding fathers, Washington, Jefferson, Franklin and Abraham Lincoln all were Calvinist, and profoundly influenced the growth and philosophy of the United States. Today, the idea of capitalism is part and parcel of the American identity. As Americans we are always thinking in terms of capitalism, even if we are not working on Wall Street. Education is viewed by many Americans as an investment in their children's future as human capital. Indeed, our society places a large proportion of wealth in the investment of education. The axiom is invest in education today for a better job or working conditions in the future. 
So to sum up, Weber saw disenchantment and the demystification of religion as one of the most important, if not the most important function of modern social life.

\section{Context and Overview of the Dialectical Relationship}

Weber suggested that early on in the development of religious salvation doctrines there is an important split into two forms creating different human identities, thus different worldviews. He illustrates this point by comparing the vessel of God salvation doctrine, and the free choice and free will salvation doctrine, which I will refer to as the ancient Judaism ethic code of behavior.

Weber stated that the vessel of God doctrine leads its followers in pursuit of "world adjustment and world flight". This produces a human identity that is passive to the masteries of nature and world occurrences. Rendering humanity to accept what is understood as God's actions and therefore without recourse, all world events have been willed by God, translating human identity into a passive being in relationship to "world occurrences", thereby reducing the human spirit to a single sentence "it is God's doing, nothing can be done"... On the other hand, Weber suggested that "for the Jew... social order of the world was conceived to have been turned into the opposite of the one promised for the future, but in the future it was to be overturned so that Jewry could be once again dominant. The world was conceived as neither eternal nor unchangeable, but rather as being created. Hence, the present structure a product of man's actions, above all those of the Jews and God's reaction to them. Hence the world was an historical product designed to give way to the truly God-ordained order... There existed in addition a highly rational religious ethic of social conduct; it was free of magic and all forms of irrational quest for salvation; it was inwardly worlds apart from the path of salvation offered by Asiatic; it was inwardly worlds apart from the path of salvation offered by Asiatic religions. To a large extent this ethic still underlies contemporary Middle Eastern and European ethic. World-historical interest in Jewry rests upon this fact... Thus, in considering the conditions of Jewry's evolution; we stand at a turning point of the whole cultural development of the West..." Bendix, Reinhard. Max Weber: an intellectual portrait, University of California Press, 1977, p. 200.

The outcome of the disenchantment of the Jewish ethic of social conduct (defined as the demystification of religion) which is free of magic and all forms of irrational quest for salvation, leads its followers in pursuit of world domination and "inner-worldliness". In addition to the above mentioned code, the Judaic mythology of knowing, and giving names to an entity is a function of power and control over that entity. Indeed, at the every least the act of naming an entity translates to an equalitarian force. By knowing the real name of an entity, there is power and dominance over that entity. (This theme occurs in many paradigms, most notably that of the Frankfurt School). Hence, for the God of Israel to materialize himself to the people of Israel and give His name as Yahweh is a major factor in the demystification, and disenchantment of religion; acting as a major pivotal point in Western Civilization toward the freedom from magic and irrational behavior.

Hence, this original work advances the following thesis: the disenchantment of the Judaic ethical code of behavior acts as a major factor in the ideology of science. This highly rational ethic leads to the disenchantment of religion which transforms the social trajectory of Western Civilization. Furthermore, this transformation propels Western Civilization into the modern ideology of science. This monumental historical shift to anthropocentrism from religious magic changing humanity's image of the world toward: 1) empirical knowledge and scientific and technological know-how led to control of the world through calculation; 2) the intellectual elaboration of the world by taking a rational, impersonal consistent and unified stance toward world domination. Hence, this monumental movement from religious ascription to personal achievement acts as a major contributing factor into the ideology of science in modern society. No longer is modern society concerned with magic; rather free will performance and recognized objective and empirical behavior is that of empirical thought $\cdots$

\section{Discussion}

Max Weber and Georg Simmel (1858-1918 two German Sociologists noted for their work on the money economy and the matter-of-fact human relationship) were brother-in-laws. As brother-in-laws they often debated the relative importance of modern capitalism (matter-of-fact behavior as Simmel put it), and disenchantment. Weber was a Christian, but Simmel was a Jew concerned with European anti-Semitism. As a result, there was the consistent debate among the two men over the "Jewish question" in Europe, and the importance of the influence of Judaic religious code on Western Civilization. Indeed, Simmel is generally known for his work in the social role as an analytical concept. The Stranger as a sociological type is an example of this analytical approach.

In the Stranger, Simmel argues that in all human relationships there is a unity of nearness and remoteness, indifference and involvement. The Stranger is close in a natural, social and general human sense. But these common features only connect us because we all are a part of the human family. As a group member the stranger is both near and far at the same time. This nearness and farness produces tensions only when the Stranger displays his/her social differences (i.e. race, religion, city vs country dweller, etc.). Simmel supports this point by identifying the social position of the Jew in Europe and the Beede tax. The Jew under the Beede tax had to pay a fixed tax per single person. On the other hand, for Christian citizens the tax was based on his changing fortune. Simmel refers to this social position because historically Europe has a long tradition of being Christian. Hence, in Europe the Jew was seen as a stranger as a result of his/her religious doctrine. Thus, this taxation policy discriminated based on the religious strangeness of the Jew in Europe.

Hence, from Simmel's work on the stranger Weber gleaned the concept of mystification and disenchantment of the Ancient Judaism Ethic Cod of Behavior as the first religious doctrine to explain the modern impersonal rational society. As was mentioned earlier, The Principle of Rationality can be viewed as the degree to which society replaces or displaces irrational thought (mysticism, superstition and concrete magic) with rational (provable and observable facts). The result of this historicalreligious transformation is disenchantment. Disenchantment can be seen as the degree to which the magical elements of thought are displaced by that of the rational, intellectual and an objective articulation of the image of the world. The masteries 
of nature and the "mystic experience" to a large extent, progress to an intellectual, impersonal, calculating image based in rules and scientific laws. Hence, this attitude seeks the "meaning of inner-worldly occurrences" through empirical and scientific thought. Thus, it is pushing back religion and the supernatural into the realm of the irrational, reducing human relations to an objective and impersonal stance resulting in: 1) world control through calculation; 2) the need for humanity to understand world occurrences; 3 ) methodical rules of order; and 4) disenchantment to be understood as the modernization and secularization of religious thought.

Moreover, Weber understood the disenchantment and secularization of the Calvinist creed of hard work and the accumulation of wealth for the purpose of "good works" acts to eliminate the traditional magical/mystical outer-worldliness philosophy, and replacing this world image with the objective, rational, and empirical stance. Indeed, this stance has metamorphosed into modern capitalism.

It is the position of this original work that the secularization (disenchantment and demystification) of the Judaic ethical code of behavior created a human identity which seeks to understand the world through a systemic orderly stance. This orderly stance is a major factor in the culmination of the ideology of science.

Weber suggested that the vessel of God doctrine leads its' followers in pursuit of "world adjustment and world flight". This produces a human identity that is passive to the masteries of nature and world occurrences rendering humanity to accept God's actions without recourse. Translating human identity into a passive being in relationship to "world occurrences", thereby reducing the human spirit to a single sentence "it is God's doing, nothing can be done".

Finally, disenchantment is the quintessential impersonal and objective human culture. Indeed, this culture rejects and condemns the irrational acts of world adjustment and world flight. Furthermore, the disenchanted attitude favors, in fact demands world mastery, shaped and modeled by human free will. Hence, this work suggests that the ideology of world mastery found in science is based upon the conviction of the objective, impersonal efficiency, certainly not by the conviction of transcendental faith and world adjustment. Lastly, it must be noted that there is no formal data or scholarship in this topic, hence this original effort is ripe for further scholarship and criticism.

\section{REFERENCES}

Andreski, S. (2010). Max Weber's insights and errors. London, New York: Routledge.

Bendix, R. (1977). Max Weber: An intellectual portrait. Berkeley, CA: University of California Press.

Burbaker, R. (2011). The limits of rationality. London, New York: Routledge.

Camic, C., Gorski, P., \& Trubek, D. (2011). Max Weber's economy and society: A critical companion. Palo Alto, CA: Stanford University Press.

Honigshrim, P. (1968). On Max Weber. New York: Free Press Publishing/Simon and Schuster.

Parsons, T. (1958). The Protestant Ethic and the Spirit of Capitalism. New York: Scrbner.

Roth, G., \& Schluchter, W. (1984). Max Weber's vision of history. Berkeley, CA: University of California Press.

Schaff, P. (1931). The creeds of Christendom, with a history and critical notes (6th ed.). New York: Harper \& Brothers.

Tribe, K. (1989). Reading Weber. London, New York: Routledge.

Turner, S., \& Factor, R. (2009). Max Weber and the dispute over reason and value. London, New York: Routledge. 